\title{
Impact of extruded flaxseed meal supplemented diet on growth performance, oxidative stability and quality of broiler meat and meat products
}

\author{
Faqir Muhammad Anjum, Muhammad Faizan Haider, Muhammad Issa Khan, Muhammad Sohaib*
}

and Muhammad Sajid Arshad

\begin{abstract}
This study was intended to explore the effect of extruded flaxseed meal supplemented diet on broiler growth performance, oxidative stability and organoleptic characteristics of broiler meat and meat products. 120 (day old) broiler chicks were randomly allotted to 12 experimental groups and fed on diets containing extruded flaxseed meal at 0,5, 10 and 15\%. The supplementation of extruded flaxseed in the diet decreases the body weight gain, feed intake and increased feed conversion ratio (FCR) values of broilers. The antioxidant enzymes were strongly influenced by different levels of extruded flaxseed supplementation among treatments. The TBARS assay revealed that maximum malondialdehyde were produced in $T_{3}$ containing highest extruded flaxseed level (15\%) and minimum malondialdehyde were produced in $T_{0}$ treatment having no extruded flaxseed. The TBARS values ranged from 0.850-2.106 and 0.460-1.052 in leg and breast met respectively. The Free radical scavenging activity varied significantly and DPPH values of breast meat ranged from $20.70 \%$ to $39.09 \%$ and in leg meat $23.53 \%$ to $43.09 \%$ respectively. The sensory acceptability of broiler meat nuggets was decreased with the increase in the level of flaxseeds due to the lipid peroxidation of polyunsaturated fatty acids (PUFA) which generated off flavors and bad odors. Feeding extruded flaxseed to chicken through feed strongly inflated the quality and functional properties, fatty acid contents and reduced the oxidative stability of broiler meat and meat products. The present study concludes that up to $10 \%$ of flaxseed meal may be used in broiler diet to enhance the omega 3 fatty acids content in the broiler meat.
\end{abstract}

Keywords: Broiler meat, Extrusion, Flaxseed, Nuggets, PUFA, Lipid stability

\section{Introduction}

Flaxseed is among unique oil seed crops because of its exceptionally high content of $\alpha$-linolenic acid (ALA), contains 35 to $45 \%$ oil, of which 45 to $52 \%$ is $\alpha$-linolenic aci [1]. Flaxseed (Linum Usitatissimum L.) is also one of the oldest domesticated crop that is under cultivation in Europe and Asia since dating back thousands of years (3000-5000 BC). Approximately more than two hundred species of flaxseed have been recognized [2]. Flaxseed is grown as oil crop, as fiber crop and oil is extracted from oilseed varieties. A large proportion of flaxseed comprises nutritional components such as oil, soluble fiber, protein, lignans, vitamins and minerals [3].

\footnotetext{
* Correspondence: ftsohaib@yahoo.com

National Institute of Food Science and Technology, University of Agriculture, Faisalabad, Pakistan
}

Nutritionists during last two decades are actually clear about selected foods that play an important role in maintaining physical and mental health status of consumers. Beyond meeting nutrition needs, it is generally recognized that dietary factors are considered to modulate detrimental development of some chronic diseases. With increased consumption of highly saturated fat foods, it seems feasible that modern diets do not meet healthy eating guidelines and deficient in certain long chain omega-3 fatty acids. It is widely accepted that inadequate intakes of omega-3 polyunsaturated fatty acids (PUFA), principally alpha-linolenic acid (ALA) and docosahexaenoic acid (DHA), adversely affect cardiovascular function [4]. Flaxseed is rich source of omega-3 polyunsaturated fatty acids and it is helpful in prevention of cardiovascular diseases and cancer. The flaxseed 
contains all essential amino acid of the protein. It is an excellent source of fiber, lecithin, vitamins and minerals. Moreover, flaxseed is of fastidious significance for its role in lowering the risk of breast and colon cancers [3]. A large proportion of flaxseed comprises nutritional valuable components such as protein (200-240 g/ kg), dietary fiber $(250-280 \mathrm{~g} / \mathrm{kg})$ and flax oil (350-450 g/kg).

The health benefits are related with the ingestion of polyunsaturated fatty acids (PUFA) and dietary fiber. The flaxseed oil contains almost 50\% essential fatty acid like alpha-linolenic acid of the total fatty acids that play a significant role in reducing the risk of coronary heart diseases [5]. However, the drawbacks with the dietary inclusion of flaxseed are the presence of anti-nutritinal factors, which may limits its utilization in poultry diets. Mucilage coming from hull, linatin dipeptide (vitmine B6 antagonistic), cyanogenic glycosides, trypsin inhibitor and phytic acid are the most important antinutritional factors found in flaxseed [6].

Alpha-linolenic acid (ALA) and linoleic acid (LA) are the essential fatty acids among the polyunsaturated fatty acids. Human body cannot synthesize alpha-linolenic acid linoleic acid so they should be present in the diet. LA and LNA are metabolized to long chain PUFA in mammalian cells. The omega- 6 fatty acid LA is converted to $\gamma$-LNA and diomo- $\gamma$-LNA by desaturase and elongase enzymes to produce arachidonic acid (AA). AA is further metabolized to eicosanoids or docosapentaenoic acid (DPA). LNA which is omega-3 fatty acid is converted to stearidonic acid and eicosatetraenoic acid to synthesize eicosapentaenoic acid (EPA) by the same enzymes used in synthesis of AA. Eicosapentaenoic acid is then metabolized to docosahexaenoic acid (DHA) or eicosanoid [7].

The limiting consumption of flaxseed is due to presence of anti-nutritional factors such as cyanogenic compounds and tannin which negatively influence the health and well-beings of the masses. The cyanogenic glycosides (CG) are amino acids derived from flaxseed constituents which release a potent cell respiration inhibitor; toxic hydrogen cyanide $(\mathrm{HCN})$ via hydrolysis. The presence of these compounds restricts flaxseed applications in feed and foodstuff by producing bitterness in final products [8]. Presence of phytic acid in the diet reduces micronutrient bioavailability and metabolizeable energy which ultimate lead towards poor growth of poultry birds. Anti-vitamin B6 compound named as "linatine" reduces dry matter and produces vitamin B6 deficiency. Omega-3 enriched meat has several health benefits. It plays an important role in prevention or treatment of cardiovascular disease, hypertension, arthrosclerosis, cancer neurological disorders and inflammatory disease. The increased intake of omega-3 fatty acids decreases serum cholesterol which beneficially affects blood pressure, skin diseases, thrombosis atherosclerosis and diabetes, arterial compliance and hyperlipidemia response [9].

Extrusion cooking is highly adaptable and focused form of processing in which food or feedstuff is enforced to flow under controlled conditions of heating and shearing through a terminal die. Extrusion processing of feed ingredients has become very popular during the last two decades. The principal features of extrusion cooking include flexible product characteristics, high energy efficiency, less space required for operation, new feed products formulations, automated control system with high productivity and product quality with no effluent showing environmental-friendly technology to be used. Optimized results for temperature $\left(146.0^{\circ} \mathrm{C}\right)$, feeding rate (32.7 kgh-1), screw speed (152.5rpm), moisture content $(12.5 \%)$ and the hydrocyanic acid removal rate (93.23\%) were founded during the extrusion detoxification technique on flaxseed via stepwise non-linear regression analysis and response surface method. It has been demonstrated that maximum removal rate of mucilage $(60.3 \%)$ from flaxseed meal can be achieved at different co-rotating twin-screw extruder die temperatures $\left(80-160^{\circ} \mathrm{C}\right)$, screw speeds $(300-900 \mathrm{rpm})$ and initial moisture contents ranged as $18.8-35.1 \%$ [10]. There exist a relationship between the stability of the flaxseed derived protein and antifungal activity with temperature variable $\left(50-90^{\circ} \mathrm{C}\right)$ using response surface methodology [11]. Regression analyses recommended the significant negative consequences on the residual antifungal activity against all test fungi using treatment variable. The protein content exits in flaxseed by means of response methodology with 5 central points and 4 axial points for independent variables [12]. Extrusion cooking improved the degradation of flaxseed mucilage and negatively influences the compact fiber structure flow behavior index with the addition of initial moisture content, high temperature and decreased screw speed [13].

Incorporation of $\mathrm{n}-3$ fatty acids from flaxseed into eggs and meat is an efficient process tool to increase the polyunsaturated fatty acids content of meat and eggs. The chicken is able to digest flaxseed in the digestive tract, absorb nutrients from flaxseed in the small intestine, and then further metabolize some of the alpha-linolenic acid (ALA; C18:3n-3), elongating and desaturating the ALA to eicosapentaenoic acid (EPA; C20:5n-3) and docosahexaenoic acid (DHA; C22:6n-3) for deposition in lipid stores such as egg yolk, and phospholipids in meat products. Flaxseed is a valuable and natural source of $n-3$ fatty acids for the poultry producer wanting to market an n-3 polyunsaturated fatty acid (PUFA) enriched poultry product. $300 \mathrm{mg}$ of omega-3fatty acids per $100 \mathrm{~g}$ of breast meat can be achieved in 26.2 days at $10 \%$ ground 
flaxseed meal [14]. Keeping in view the breakthrough results in flaxseed or flaxseed meal studies, the present study was carried out to compare the effects of extruded flaxseed meal supplementation on broiler growth performance, oxidative stability, ALA, polyunsaturated fatty acids content, quality attributes of broiler meat and sensory acceptability of meat products.

\section{Materials and methods \\ Composition of diet}

The composition of the control feed was $300 \mathrm{~g}$ of corn, $200.0 \mathrm{~g}$ of soya been meal of $44 \%$ protein, $140.0 \mathrm{~g}$ of Sorghum, $100.0 \mathrm{~g}$ of sunflower meal, $60 \mathrm{~g}$ of barley, $50 \mathrm{~g}$ of rye, $50.0 \mathrm{~g}$ of beef tallow, $20 \mathrm{~g}$ of dicalcium phosphate, $2 \mathrm{~g}$ of sodium bicarbonate, $10 \mathrm{~g}$ of salt and $10.0 \mathrm{~g}$ of Sepiolite per $\mathrm{kg}$ of feed. The analysis of feed revealed that metabolizable energy of the control feed was $2850 \mathrm{kcal} / \mathrm{kg}$, crude protein (16.0\%), crude fat (4.1\%) fiber (5.1\%) and ash content was (7.4\%). Additionally flaxseed was supplemented in the feed at a level of 5, 10 and $15 \%$ as mentioned in the treatment plan (Table 1).

\section{Extrusion of flaxseed}

Hammered milled flaxseed was extruded using the single screw extruder, Extru-tech E325 (Extru-tech, Sabetha, Kansas). Designed single screw extruder was consisting of feed delivery system, heating arrangement, preconditioning system, power transmission system and extruder barrel. Optimum pre-conditioning was carried out by the addition of steam in the pre-conditioner part of extruder prior extrusion heating of flaxseed. The conditions for extrusion of flaxseed were extruder final head temperature $\left(80-120^{\circ} \mathrm{C}\right)$, extruder barrel speed (80-120rpm) and feeder speed (12-16rpm) as described by [15]. The extruded flaxseed was then added to broiler diet.

\section{Experimental birds management}

One day old (120) broiler chicks of Hubbard strain were purchased from local market. The chicks were weighed individually and then randomly divided in to 12 experimental units of 10 birds each. These units were further allotted to 4 treatments in such a way that each treatment has 3 replicates. The birds were kept in a student reserved research room having 31 pens of 12 sq feet capacity each. The room and the pens were cleaned thoroughly, white washed and then disinfected with formalin with a ratio 1:12 inside and outside the pen before the start of experiment. A layer of saw dust was used as litter in each pen that was stirred regularly during the experiment to keep it in dry condition. The temperature of the experimental room was maintained at $95^{\circ} \mathrm{F}$ during the first week. It was then lowered by $5^{\circ} \mathrm{F}$ till it reached $75 \mathrm{~F}^{\circ} \pm 2$. Twenty four hour light and proper ventilation was provided in the experimental room throughout the experimental period. Feed along with fresh and clean water was given ad-libitum. The experimental birds were reared up to six weeks. First two weeks, the chicks were fed on the control feed and after the four weeks the feed was supplemented with extruded flaxseed.

\section{Sample collection}

After the completion of the 6 weeks, the birds were slaughtered according to the Halal ethical guidelines of slaughtering set by the university and white (breast) and red meat (leg) were separated and packaged in polythene zip lock bags and stored at $-18^{\circ} \mathrm{C}$ for further analysis.

\section{Analysis of broiler meat}

\section{Sample preparation for analysis}

5 gram meat sample was taken in $50 \mathrm{ml}$ polypropylene tube having a cap and sample homogenized by using phosphate buffer and glycerol (20\%) pH (7.4) with the help of homogenizer. During the process of homogenization, tubes were placed in ice cold water to dissipate the heat. Filtration process was done to remove connective tissues from sample by using muslin cloth.

\section{Enzyme assay}

The superoxide dismutase (SOD) activity was determined by measuring the ability of enzyme to inhibit cytochrome 'c' oxidation [16]. The catalase (CAT) activity was measured by observing decomposition of hydrogen peroxide [17] and one international unit (IU) was equivalent to one mmole $\mathrm{H}_{2} \mathrm{O}_{2}$ consumed $/ \mathrm{min} / \mathrm{mg}$ protein. The Glutathione peroxidase (GPX) activity was estimated by using the method of [18] and activity was measured as nmol of $\mathrm{NADPH} / \mathrm{min} / \mathrm{mg}$ Protein. The Glutathione reductase (GR) activity was assayed by following the reduction of glutathione [19].

\section{1, 1-diphenyl-2-picrylhdrazyl (DPPH) scavenging activity}

The free radical scavenging activity of leg and breast meat was determined by following modified method of [20]. Meat sample having protein concentration $(1 \mathrm{mg} /$ $1 \mathrm{~mL}$ ) took $100 \mu \mathrm{L}$ fraction volumes in a test tube. Freshly prepared 0.0012M DPPH (1, 1-diphenyl-2- picrylhydrazyl) in methanol solution was added $2 \mathrm{~mL}$ in tubes containing $100 \mu \mathrm{L}$ volume of sample. The reaction was incubating for 30 minute at room temperature in dark place. Absorbance

Table 1 Treatment plan of experimental birds

\begin{tabular}{cc}
\hline Treatments & Treatments combination \\
\hline$T_{0}$ & Control \\
$T_{1}$ & Control $+5 \%$ extruded flaxseed \\
$T_{2}$ & Control $+10 \%$ extruded flaxseed \\
$T_{3}$ & Control $+15 \%$ extruded flaxseed \\
\hline
\end{tabular}


of resultant mixture was recorded at $517 \mathrm{~nm}$ against blank and control using UV/Vis. spectrophotometer.

\section{Thiobarbituric acid reactive substances (TBARS) assay}

The oxidative stability of omega enriched broiler meat was determined by using TBARS assay [21]. Ferrous sulphate and hydrogen peroxides were added to start the peroxidative reaction. The solution was placed in water bath at $37^{\circ} \mathrm{C} .1 \mathrm{ml}$ sample was taken from reaction mixture in glass tube and $2 \mathrm{ml}$ TBARS/TCA solution was added. Test tubes were placed in water bath at $90^{\circ} \mathrm{C}$ and kept for 30 minutes and then cooled. Then centrifugation was done and the absorbance was recorded at $532 \mathrm{~nm}$ and lipid peroxidaton was calculated by using the formula

$$
\begin{aligned}
\mathrm{n} & -\begin{array}{l}
\text { Mole of malondialdehyde } \\
(\text { Sample absorbance }- \text { blank }) \times \text { Total sample volume }
\end{array} \\
& =\frac{.000156 \times 1000(\text { per } \mathrm{mL})}{}
\end{aligned}
$$

\section{Fatty acids profile of broiler meat}

The polyunsaturated fatty acid content of omega three enriched broiler meat was determined by using gas liquid chromatography [22]. Lipids from meat samples were extracted using a non-polar solvent, n-hexane (GC-grade). The fatty acids profile of extracted lipids were prepared and analyzed according to the AOCS (1998) Method No. Ce 1f-96. $50 \mu$ l oil sample was methyated in the presence of $4 \mathrm{~mL} \mathrm{KOH}(1 \mathrm{M})$ at room temperature for one hour in order to produce fatty acids methyl esters. The resultant methyl esters were extracted with GC grade n-hexane for immediately analyzing by Gas Chromatograph (Agilent Technologies, 6890N) equipped with an auto sampler, flame-ionization detector (FID) and fused capillary column (Silica $30 \mathrm{~m} \times$ 0.25 film thickness) apparatus. Samples $(1 \mu \mathrm{L})$ were injected with Nitrogen $(3.5 \mathrm{~mL} / \mathrm{min})$ as a carrier gas onto the column, which was programmed for operating conditions such as column oven temperature $220^{\circ} \mathrm{C}$ for 7.5 minutes, split ratio (50\%) with injector and detector temperatures $\left(260^{\circ} \mathrm{C}\right)$. Peak areas and total fatty acids profile percentages were calculated for each sample by retention time using Agilent Chem. Station software. The standards of fatty acids methyl esters purchased from Sigma-Aldrich were also run under the same conditions for comparison with experimental samples.

\section{Product development \\ Preparation of nuggets}

The nuggets of omega 3 enriched broiler meat were prepared by the method described by [23]. The basic recipe of the nuggets is as Chicken boneless $500 \mathrm{~g}$, Egg 1, oil as required for frying, Black pepper $12 \mathrm{~g}$, Garlic paste $10 \mathrm{~g}$,
Onion 100 g, Plain flour 120 g, Bread crumbs 70 g, salt 20 g. Hand deboned chicken breasts and leg meat was separated and utilized for the development of the nuggets. Breast and leg meat was minced separately with respective additives as mentioned in the recipe of nuggets. All ingredients were mixed and then uniformly blended to obtain a uniform mixture. Then sheeting was done and nuggets were shaped into $30 \mathrm{~mm}$ diameter. After nuggets were prepared, they were dipped in plain flour and bread crumbs separately. The frying of the nuggets was done in canola oil at $180^{\circ} \mathrm{C}$ till golden brown color was appeared.

\section{Physico-chemical analysis of nuggets}

The $\mathrm{pH}$ of Nuggets was measured by using $\mathrm{pH}$ meter by following the method as described by [24]. The colour of nuggets was measured by using a hand held tristimulus colorimeter (Color Test Meter II) at regular storage intervals $(0,10,20,30$ days $)$ as described by [25]. The water activity of Nuggets was determined by using an electronic Hygropalm water activity meter (Model Aw-Win, Rotronic, equipped with a Karl-Fast probe) as described by [26] The textural characteristics of sausages were analyzed at different storage intervals by means of texture analyzer (Mod. TA-XT2, Stable Microsystems, surrey, UK) Texture was determined with the help of texture analyzer (model TA_XT Plus, Stable Microsystems, Surrey, UK) as described by [27].

\section{Sensory evaluation of nuggets}

The sensory evaluation of fried nuggets was carried out for the different attributes like color, appearance, taste, texture and off flavor production by using nine point hedonic scale after $0,10,20$ and 30 days, by using the method as described [28] by trained panelists as the method described.

\section{Statistical analysis}

The data obtained for each parameter was subjected to statistical analysis to determine the level of significance by using the software package (Statistic 8.1) according to the method described [29]. The Duncan's multiple range (DMR) test was used to estimate the level of significance that existed between the mean values.

\section{Results and discussion}

\section{Growth parameters}

The results in (Table 2) showed that there was a highly significant effect of different treatments of extruded flaxseed on weight gain of the broiler birds. $\mathrm{T}_{0}$ control treatment having no extruded flaxseed gained highest weight $960.61 \mathrm{~g}$ followed by the $\mathrm{T} 1$ containing $5 \%$ extruded flaxseed having weight $931.56 \mathrm{~g}$ and $\mathrm{T}_{2}$ containing $10 \%$ extruded flaxseed 891.61 and $\mathrm{T}_{3}$ containing maximum extruded flaxseed 15\% 
Table 2 Body weight gain (g/week)) and feed conversion ratio of the broiler birds fed on extruded flaxseed on weekly basis

\begin{tabular}{|c|c|c|c|c|}
\hline \multirow{4}{*}{$\begin{array}{l}\text { Study } \\
\text { weeks }\end{array}$} & \multicolumn{4}{|c|}{ Dietary treatment } \\
\hline & Control (C) & (C) & (C) & (C) \\
\hline & & + & + & + \\
\hline & & $5 \%$ EFM & $10 \%$ EFM & $15 \%$ EFM \\
\hline Wk-1 & $94.0 \pm 3$ (BWG) $1.71 \pm 0.04$ (FCR) & $94.3 \pm 2(\mathrm{BWG}) 1.69 \pm 0.09(\mathrm{FCR})$ & $93.7 \pm 4(\mathrm{BWG}) 1.68 \pm 0.03(\mathrm{FCR})$ & $92.7 \pm 5(\mathrm{BWG}) 1.73 \pm 0.10(\mathrm{FCR})$ \\
\hline Wk-2 & $332 \pm 11$ (BWG) $1.53 \pm 0.07(F C R)$ & $315 \pm 14(\mathrm{BWG}) 1.65 \pm 0.09(\mathrm{FCR})$ & $302 \pm 21(\mathrm{BWG}) 1.75 \pm 0.15(\mathrm{FCR})$ & $289 \pm 27(\mathrm{BWG}) 1.86 \pm 0.20$ (FCR) \\
\hline Wk-3 & $644 \pm 20$ (BWG) $1.86 \pm 0.11(F C R)$ & $631 \pm 20$ (BWG) $1.79 \pm 0.08(F C R)$ & $600 \pm 39$ (BWG) $1.86 \pm 0.07(F C R)$ & $560 \pm 14(\mathrm{BWG}) 2.03 \pm 0.19(\mathrm{FCR})$ \\
\hline Wk-4 & $1054 \pm 33(\mathrm{BWG}) 1.83 \pm 0.15(\mathrm{FCR})$ & $1018 \pm 30(\mathrm{BWG}) 1.91 \pm 0.14(\mathrm{FCR})$ & $977 \pm 45(\mathrm{BWG}) 1.94 \pm 0.15(\mathrm{FCR})$ & $926 \pm 38$ (BWG) $1.98 \pm 0.20$ (FCR) \\
\hline Wk-5 & $1582 \pm 47$ (BWG) $1.81 \pm 0.24(F C R)$ & $1542 \pm 41$ (BWG) $1.82 \pm 0.28(F C R)$ & $1470 \pm 35(\mathrm{BWG}) 1.90 \pm 0.24(\mathrm{FCR})$ & $1408 \pm 33(\mathrm{BWG}) 1.93 \pm 0.25(\mathrm{FCR})$ \\
\hline Wk-6 & $2058 \pm 54$ (BWG) $2.31 \pm 0.30$ (FCR) & $1989 \pm 45(\mathrm{BWG}) 2.38 \pm 0.32(\mathrm{FCR})$ & $1907 \pm 48$ (BWG) $2.41 \pm 0.29(\mathrm{FCR})$ & $1824 \pm 42(\mathrm{BWG}) 2.48 \pm 0.31(\mathrm{FCR})$ \\
\hline $\begin{array}{l}\text { Means } \\
\pm \text { SD }\end{array}$ & $960.61 \pm 28 \mathrm{~A}(\mathrm{BWG}) 1.84 \pm 0.15 \mathrm{~B}(\mathrm{FCR})$ & $931.56 \pm 25 \mathrm{~B}(\mathrm{BWG}) 1.88 \pm 0.16 \mathrm{~B}$ (FCR) & $891.61 \pm 32 \mathrm{C}(\mathrm{BWG}) 1.93 \pm 0.15 \mathrm{AB}(\mathrm{FCR})$ & $850.06 \pm 26 \mathrm{D}$ (BWG) $2.00 \pm 0.20 \mathrm{~A}(\mathrm{FCR})$ \\
\hline
\end{tabular}

gained lowest weight $850.06 \mathrm{~g}$. The weight gain performance of broilers was affected negatively by the increased level of extruded flaxseed. The results of my study match with the finding of [30]. They observed that the flaxseed depressed the body weight gain in the broiler birds. The depression in bird performance appears to be due to poor energy availability [31]. The feed intake of broiler birds was significantly affected by different treatments of extruded flaxseed. Feed intake increased with the increase in time period and decreased with the increase in extruded flaxseed level. $\mathrm{T}_{0}$ contains no flaxseed showed highest feed intake $651.44 \mathrm{~g}$ and the $\mathrm{T}_{3}$ containing maximum level of extruded flaxseed showed the lowest feed intake 626.89g. $\mathrm{T}_{1}(640.8 \mathrm{~g})$ and $\mathrm{T}_{2}$ (633.6) the feed intake was higher than the $\mathrm{T}_{3}$ but lower than the $\mathrm{T}_{0}$. The results of my study are in agreement with the finding of [32] who stated that the feed intake decreased with high level of flaxseed in bird's feed. The feed intake may be reduced due to the high fat contents in the extruded flaxseed supplemented diet. The other factor that is important in lowering the feed intake is the antinutritional factor present in flaxseed even after the extrusion of flaxseed. The feed conversion ratio is the ratio between weight gain and feed intake of birds and represents the efficiency of birds to convert feed into body weight. The results for feed conversion ratio showed the significant effect of different treatments of extruded flaxseed on feed conversion ratio of broilers. The feed conversion ratio increased with the increase in the extruded flaxseed level. $\mathrm{T}_{3}$ showed the highest FCR (2.007) followed by $\mathrm{T}_{2}$ (1.93), $\mathrm{T}_{1}$ (1.88) and minimum was observed in $\mathrm{T}_{0}$ as (1.845). The highest FCR value in high extruded flaxseed treatment is due to the less weight gain in the broiler birds. The results of my study are in close collaboration with the [33] who stated that the bird fed with high flaxseed levels have high FCR values which may be due to the low digestibility and high viscosity of jejunal digesta.

\section{Enzyme assay of broiler blood}

All living organisms have natural defence system against the free radicals produced by the consumption of oxygen. This defence system contains different types of antioxidant enzyme. Most important enzyme are superoxide dismutase (SOD), catalase (CAT), glutathione peroxidise $(\mathrm{GSH}-\mathrm{Px})$ and glutathione reductase (GR). The results (Table 3) revealed significant effect of different treatments of extruded flaxseed on the different enzymes assay in the plasma of the broiler blood. The superoxide dismutase activity ranged from 2.80 to $3.22 \mathrm{U} / \mathrm{ml} . \mathrm{T}_{3}$ showed the highest $3.22 \mathrm{U} / \mathrm{ml}$ superoxide dismutase activity while $T_{1}$ and $T_{2}$ were also affected significantly as compared to control treatment. The catalase activity of blood ranged from 36.38 to 45.42 (mmol of $\mathrm{H}_{2} \mathrm{O}_{2}$ decomposed $/ \mathrm{min} / \mathrm{mg}$ ). Catalase activity increases toward the treatment $\mathrm{T}_{3}$ (45.42) which have maximum level of extruded flaxseed. $\mathrm{T}_{1}$ and $\mathrm{T}_{2}$ also affected the catalase activity (38.75 and 42.46) as compared to the control treatment (36.38). The catalase activity is related to the SOD activity because SOD convert superoxide radicals to hydrogen peroxide. More production of the superoxide radicals more will be the activity of SOD and hence more the activity of catalase. The values for GSHPx ranged from 2.33 to 3.23 . The highest glutathione peroxidase activity was observed in $\mathrm{T}_{3}$ (3.23) and the minimum in $\mathrm{T}_{0}$ (2.3). The higher GSH-Px values higher will be the oxidation. Lipid oxidation and cholesterol oxidation were also positively correlated with the GSHPx activity. GSH-Px activity can be used as an indicator of the meat oxidative stability. The higher GSH-Px activities observed for the different treatments of extruded flaxseed may be due to the higher content of PUFA of diet. The results of my study are in agreement with [34]. Glutathione reductase (GR) activity in different treatment ranged from 3.93 to $4.33 \mathrm{u} / \mathrm{g}$ of protein. The 
Table 3 Antioxidant enzymes of blood serum of broiler birds fed on different levels of extruded flaxseed through feed

\begin{tabular}{ccccc}
\hline Treatments & $\begin{array}{c}\text { SOD (50\% Pyrogyllol } \\
\text { auto-oxidation/min/mg) }\end{array}$ & $\begin{array}{c}\text { CAT ( } \mathbf{m m o l} \text { of } \mathbf{H}_{\mathbf{2}} \mathbf{O}_{\mathbf{2}} \\
\text { decomposed } / \mathbf{m i n} / \mathbf{m g})\end{array}$ & $\begin{array}{c}\text { GSH-Px activity (nmol NADPH/ } \\
\mathbf{m i n} / \mathbf{m g} \text { Protein) }\end{array}$ & $\begin{array}{c}\text { Glutathione reductase } \\
\text { (u/g protein) }\end{array}$ \\
\hline $\mathbf{T}_{\mathbf{0}}$ & $2.80 \pm 0.06 \mathrm{~d}$ & $36.38 \pm 0.88 \mathrm{~d}$ & $2.33 \pm 0.06 \mathrm{C}$ & $3.93 \pm 0.06 \mathrm{C}$ \\
$\mathbf{T}_{\mathbf{1}}$ & $2.99 \pm 0.01 \mathrm{C}$ & $38.75 \pm 1.04 \mathrm{c}$ & $2.45 \pm 0.05 \mathrm{C}$ & $4.07 \pm 0.05 \mathrm{~b}$ \\
$\mathbf{T}_{\mathbf{2}}$ & $3.09 \pm 0.03 \mathrm{~b}$ & $42.46 \pm 0.82 \mathrm{~b}$ & $2.93 \pm 0.04 \mathrm{~b}$ & $4.26 \pm 0.04 \mathrm{a}$ \\
$\mathbf{T}_{\mathbf{3}}$ & $3.22 \pm 0.03 \mathrm{a}$ & $45.42 \pm 0.88 \mathrm{a}$ & $3.23 \pm 0.09 \mathrm{a}$ & $4.33 \pm 0.06 \mathrm{a}$ \\
\hline
\end{tabular}

Values are mean of three replicates \pm SD. Means followed by different letters are significant different $(p<0.05)$.

activity of the GR increased towards the treatment containing high amount of extruded flaxseed. $\mathrm{T}_{3}$ showed maximum activity $4.33 \mathrm{u} / \mathrm{g}$. GR activity is induced by the by the unsaturated and polyunsaturated fats as compared to the saturated fats. The increase in activity of GR in red blood cells is a positive feedback mechanism in response to rising lipid peroxidation [35].

\section{Oxidative stability of broiler meat}

Thiobarbituric acid reactive substances (TBARS) assay

Lipid peroxidation is the most important factor of quality deterioration in meat. The thiobarbuturic acid assay is a practical method for the determination of food lipid peroxidation. The results (Table 4) revealed a highly significant effect of different treatments of extruded flaxseed on TBARS value of leg and breast muscles of broilers. Leg meat TBARS values ranged from 0.850-2.106. $\mathrm{T}_{0}$ control treatment having no extruded flaxseed showed the minimum TBARS value 0.850 and $\mathrm{T}_{3}$ containing highest extruded flaxseed level (15\%) showed the maximum TBARS value 2.106. $\mathrm{T}_{1}$ and $\mathrm{T}_{2}$ have TBARS values 1.289 and 1.856 respectively. The increasing trend in TBARS values was observed as the level of extruded flaxseed increased. High oxidative deterioration in broiler meat is due to its high concentration of polyunsaturated fatty acids [36]. The results of my study are similar with the findings of [14] who observed that the TBARS values were higher in higher level of flaxseed feeding to broiler birds. Breast meat also exhibited the same pattern as leg meat. $\mathrm{T}_{3}$ showed the highest TBARS value1.052 as compared to $T_{1}$ and $\mathrm{T}_{2}$ which were 0.588 and 0.796 respectively. TBARS values were higher in all treatments of extruded flaxseed as compare to the control treatment. Results of my study are agreed with [37]. The TBARS values were less in breast meat as equate with leg meat and it may be due to the less amount of fat contents in the breast meat. The results (Table 4) revealed that all the treatments of extruded flaxseed significantly affected the free radical scavenging activity. The free radical scavenging activity of leg meat ranged from 22.58 to $43.94 \%$ while in breast meat ranged from 20.70 to 39.09 . The reason might be that high flaxseed feeding in diet results in high free radical scavenging activity and lignans play vital role in the raising the freed radial scavenging activity.

\section{Fatty acid analysis of broiler meat}

The fatty acid profile (mg/100 g of meat) corresponding to leg and breast meat is shown in Table (5) and it revealed that palmitic acid contents in leg meat ranged from 58.64 to $62.73(\mathrm{mg} / 100 \mathrm{~g})$. It is cleat form results that the maximum value of palmitic acid (62.73) was found in $\mathrm{T}_{3}$ followed by $\mathrm{T}_{2}$ (61.77), $\mathrm{T}_{0}$ (58.64) and $\mathrm{T}_{1}$ (57.97) While the breast meat contained 55.87 to 6.91 (mg/100 g) palmitic acid. The results regarding stearic acid showed that there was maximum stearic acid present in $\mathrm{T}_{3}$ (44.68) and minimum was observed in $\mathrm{T}_{0}$ (33.65) in leg meat. The stearic acid contents in breast meat ranged from 27.65 to 37.59 . The GC analysis pertaining to oleic acid contents of leg meat was presented in Table (4.21). Oleic acid contents ranged from 59.87 to

Table 4 Total Lipids, TBARS assay, Free radical scavenging activity of leg and breast meat of broilers fed on extruded flaxseed meal supplemented diet

\begin{tabular}{|c|c|c|c|c|c|c|}
\hline \multirow[t]{3}{*}{ Treatments } & \multicolumn{6}{|c|}{ Meat type } \\
\hline & \multicolumn{3}{|c|}{ Breast meat } & \multicolumn{3}{|c|}{ Leg meat } \\
\hline & Total lipids (\%) & $\begin{array}{c}\text { TBARS assay (nmol of } \\
\text { malondialdehyde/mg } \\
\text { of meat) }\end{array}$ & $\begin{array}{c}\text { Free radical scavenging } \\
\text { activity (\%) }\end{array}$ & Total lipids (\%) & $\begin{array}{c}\text { TBA assay (nmol of } \\
\text { malondialdehyde/mg } \\
\text { of meat) }\end{array}$ & $\begin{array}{c}\text { Free radical scavenging } \\
\text { activity (\%) }\end{array}$ \\
\hline $\mathrm{T}_{0}$ & $7.88 \pm 0.4 b$ & $0.460 \pm 0.03 d$ & $19.87 \pm 1.1 c$ & $9.97 \pm 0.5 d$ & $0.850 \pm 0.01 d$ & $23.53 \pm 1.1 d$ \\
\hline $\mathbf{T}_{1}$ & $8.10 \pm 0.4 b$ & $0.588 \pm 0.01 c$ & $25.98 \pm 3.9 b$ & $12.80 \pm 0.5 c$ & $1.289 \pm 0.03 c$ & $28.30 \pm 1.8 \mathrm{c}$ \\
\hline $\mathbf{T}_{2}$ & $8.63 \pm .0 .4 a$ & $0.796 \pm 0.01 b$ & $33.13 \pm 2.6 a$ & $15.10 \pm 0.8 b$ & $1.856 \pm 0.03 b$ & $35.25 \pm 2.6 b$ \\
\hline$T_{3}$ & $8.96 \pm 0.3 a$ & $1.052 \pm 0.01 a$ & $38.27 \pm 2.6 a$ & $18.92 \pm 0.7 a$ & $2.106 \pm 0.02 a$ & $43.09 \pm 1.1 \mathrm{a}$ \\
\hline
\end{tabular}

Values are mean of three replicates \pm SD. Means followed by different letters are significant different $(p<0.05)$. 
70.52. Maximum oleic acid contents was present in $\mathrm{T}_{2}$ (7.52) followed by $\mathrm{T}_{3}$ (68.99). The breast meat oleic acid contents ranged from 56.22 to 66.57 . Highest oleic acid contents were found in $\mathrm{T}_{3}$ (66.57). Linoleic acid contents in leg meat ranged from 69.12 to75.68. $\mathrm{T}_{3}$ showed the highest linoleic contents (75.68) followed by $\mathrm{T}_{1}$ (74.31) and $\mathrm{T}_{2}$ (73.36). The breast meat linoleic contents ranged from 51.88 to 74.14. Minimum linoleic contents were observed in $\mathrm{T}_{1}$ (51.88). Omega-3 fatty acid (linolenic acid) ranged from 3.98 to 9.52. Maximum lilenic acid was present in $\mathrm{T}_{3}$ (9.52) followed by $\mathrm{T}_{2}$ (8.41), $\mathrm{T}_{1}$ (6.10) and $\mathrm{T}_{0}$ (3.98). Breast meat contained linolenic acid in the range of 1.96 to 3.24 . The linolenic acid contents in breast meat were less as compared to the thigh meat. Thigh meat fatty acid profile was highly enriched by the different concentrations of extruded flaxseed in the diet of birds. The higher addition of linolenic acid in fatty acid profile of leg meat was due to its high capacity of modification in lipid fraction. The results agreed with Zuidhof et al. (2009). Similar results were reported in rabbits when fed with different levels of flaxseed [38] and in pork [39]. All these authors reported that there was significant increase in polyunsaturated fatty acid contents of fatty acid profile when the flaxseed was given through the diet to the broilers.

\section{Physico-chemical analysis of nuggets}

$\mathrm{pH}$ of the nuggets is an important factor in the determination of the shelf life and storage stability of the nuggets. The results (Table 6) revealed the treatments have no significant effect on the $\mathrm{pH}$ of the nuggets while the storage affected the $\mathrm{pH}$ significantly at freezing storage conditions. However, the interactive effect of storage days and different treatments of flaxseed was also non significant. At day $0, \mathrm{~T}_{0}$ had $\mathrm{pH}$ value 6.64 which reduced to 6.59 at day $30 . \mathrm{T}_{1}$ showed the same pattern at 0 day $\mathrm{pH}$ value of nuggets was 6.66 which decreased to 6.61 at day 10 and 6.58 at day 20 and ultimately 6.50 at day $30 . \mathrm{T}_{2}$ also showed the decrease in $\mathrm{pH}$ during storage. The $\mathrm{pH}$ was decreased from 6.77 to 6.61 from 0 to 30 days. $T_{3}$ followed the same pattern as $T_{0}, T_{1}$ and $\mathrm{T}_{2}$ the pH 6.71 at 0 days decreased up to 6.54 at day 30 . The results of present study are in close collaboration with [40] who stated that $\mathrm{pH}$ value of omega enriched frankfurters decreased with the advancement of storage period.

Table 5 Fatty acid profile of breast and leg meat of broilers fed on extruded flaxseed meal supplemented diet

\begin{tabular}{|c|c|c|c|c|c|c|c|c|}
\hline \multirow[t]{3}{*}{ Treatments } & \multicolumn{8}{|c|}{ Meat type } \\
\hline & \multicolumn{4}{|c|}{ Breast meat } & \multicolumn{4}{|c|}{ Leg meat } \\
\hline & $\mathrm{T}_{0}$ & $T_{1}$ & $\mathrm{~T}_{2}$ & $T_{3}$ & $\mathrm{~T}_{0}$ & $T_{1}$ & $T_{2}$ & $T_{3}$ \\
\hline $\mathrm{C} 8$ & 0.28 & 0.31 & 0.27 & 0.26 & 0.27 & 0.27 & 0.25 & 0.26 \\
\hline C10 & 0.45 & 0.47 & 0.43 & 0.41 & 0.41 & 0.41 & 0.4 & 0.39 \\
\hline $\mathrm{C} 14,0$ & 0.52 & 0.63 & 0.51 & 0.49 & 0.57 & 0.56 & 0.55 & 0.54 \\
\hline $\mathrm{C} 16,0$ & 55.87 & 58.76 & 57.42 & 60.91 & 58.64 & 57.97 & 61.77 & 62.73 \\
\hline $\mathrm{C} 16,1$ & 1.92 & 1.94 & 1.91 & 1.89 & 1.98 & 2.01 & 1.93 & 1.91 \\
\hline $\mathrm{C} 17,0$ & 0.32 & 0.33 & 0.3 & 0.31 & 0.2 & 0.19 & 0.18 & 0.17 \\
\hline $\mathrm{C} 17,1$ & 0.19 & 0.2 & 0.18 & 0.17 & 0.07 & 0.06 & 0.07 & 0.05 \\
\hline$C, 18,0$ & 27.65 & 25.72 & 33.45 & 37.59 & 33.65 & 40.61 & 39.52 & 44.68 \\
\hline $\mathrm{C} 18,1$ & 56.22 & 60.62 & 59.12 & 66.57 & 33.29 & 35.29 & 33.05 & 32.17 \\
\hline $\mathrm{C} 18,2$ & 54.81 & 51.88 & 68.74 & 74.14 & 69.12 & 74.31 & 73.36 & 75.68 \\
\hline $\mathrm{C} 18,3$ & 1.96 & 2.76 & 3.02 & 3.24 & 3.98 & 6.1 & 8.41 & 9.52 \\
\hline$C 20,4$ & 5.88 & 5.87 & 5.87 & 5.8 & 5.48 & 5.5 & 5.44 & 5.26 \\
\hline $\mathrm{C} 22,0$ & 0 & 0.09 & 0 & 0 & 0 & 0.1 & 0 & 0 \\
\hline $\mathrm{C} 22,1$ & 0 & 0.13 & 0 & 0 & 0 & 0.15 & 0 & 0 \\
\hline $\mathrm{C} 22,5$ & 0.09 & 0.07 & 0.08 & 0.08 & 0.11 & 0.1 & 0.09 & 0.1 \\
\hline $\mathrm{C} 22,6$ & 12.22 & 17.66 & 23.11 & 27.65 & 11.55 & 19.23 & 23.12 & 26.67 \\
\hline SFA & 57.44 & 86.31 & 92.38 & 99.97 & 93.74 & 100.11 & 102.67 & 108.77 \\
\hline MUFA & 58.33 & 62.89 & 61.21 & 68.63 & 35.34 & 37.51 & 35.05 & 34.13 \\
\hline PUFA & 74.96 & 78.37 & 100.82 & 110.91 & 90.24 & 105.39 & 110.42 & 117.23 \\
\hline US & 133.29 & 141.26 & 162.03 & 179.54 & 125.58 & 142.9 & 145.47 & 151.36 \\
\hline Total & 190.73 & 227.57 & 254.41 & 279.51 & 219.32 & 243.01 & 248.14 & 260.13 \\
\hline
\end{tabular}


Table $6 \mathrm{pH}$, water activity, color and texture values of nuggets of leg and breast meat of broilers fed on extruded flaxseed meal supplemented diet

\begin{tabular}{|c|c|c|c|c|c|c|c|c|c|c|}
\hline \multirow{2}{*}{$\frac{\text { Treatment }}{\mathrm{pH}}$} & \multicolumn{5}{|c|}{ Breast meat nuggets } & \multicolumn{5}{|c|}{ Leg meat nuggets } \\
\hline & 0 day & 10 day & 20 day & 30 day & Mean & 0 day & 10 day & 20 day & 30 day & Mean \\
\hline $\mathrm{T}_{0}$ & $6.69 \pm 0.03$ & $6.63 \pm 0.02$ & $6.60 \pm 0.02$ & $6.56 \pm 0.07$ & $6.62 \pm 0.05 \mathrm{ab}$ & $6.64 \pm 0.05$ & $6.64 \pm 0.06$ & $6.63 \pm 0.02$ & $6.59 \pm 0.04$ & $6.6267 \pm 0.02 \mathrm{a}$ \\
\hline $\mathrm{T}_{1}$ & $6.64 \pm 0.07$ & $6.60 \pm 0.05$ & $6.58 \pm 0.07$ & $6.53 \pm 0.05$ & $6.58 \pm 0.04 b$ & $6.66 \pm 0.06$ & $6.61 \pm 0.03$ & $6.58 \pm 0.07$ & $6.50 \pm 0.03$ & $6.5883 \pm 0.06 a b$ \\
\hline $\mathrm{T}_{2}$ & $6.77 \pm 0.11$ & $6.64 \pm 0.05$ & $6.62 \pm 0.02$ & $6.61 \pm 0.04$ & $6.66 \pm 0.07 a$ & $6.64 \pm 0.07$ & $6.62 \pm 0.02$ & $6.55 \pm .0 .09$ & $6.50 \pm 0.02$ & $6.5783 \pm 0.06 \mathrm{~b}$ \\
\hline$T_{3}$ & $6.71 \pm 0.11$ & $6.66 \pm 0.07$ & $6.57 \pm 0.07$ & $6.54 \pm 0.03$ & $6.62 \pm 0.07 a b$ & $6.65 \pm 0.04$ & $6.59 \pm 0.05$ & $6.58 \pm 0.06$ & $6.49 \pm 0.03$ & $6.5750 \pm 0.06 \mathrm{~b}$ \\
\hline Mean & $6.70 \pm 0.05 a$ & $6.63 \pm 0.02 b$ & $6.59 \pm 0.02 \mathrm{bc}$ & $6.56 \pm 0.03 c$ & & $6.65 \pm 0.01 a$ & $6.62 \pm 0.02 \mathrm{ab}$ & $6.59 \pm 0.03 b$ & $6.52 \pm 0 . c$ & \\
\hline \multicolumn{11}{|c|}{ Water activity } \\
\hline$T_{0}$ & $0.683 \pm 0.005$ & $0.667 \pm 0.002$ & $0.663 \pm 0.005$ & $0.655 \pm 0.004$ & $0.6669 \pm 0.01 a$ & $0.671 \pm 0.003$ & $0.670 \pm 0 . .004$ & $0.660 \pm 0.004$ & $0.654 \pm 0.002$ & $0.6638 \pm 0.008 a$ \\
\hline $\mathrm{T}_{1}$ & $0.678 \pm 0.004$ & $0.672 \pm 0.003$ & $0.670 \pm 0.005$ & $0.647 \pm 0.005$ & $0.6668 \pm 0.01 a$ & $0.664 \pm 0.004$ & $0.660 \pm 0.005$ & $0.658 \pm 0.004$ & $0.648 \pm 0.002$ & $0.6575 \pm 0.006 b$ \\
\hline $\mathrm{T}_{2}$ & $0.673 \pm 0.005$ & $0.668 \pm 0.005$ & $0.662 \pm 0.007$ & $0.659 \pm 0.003$ & $0.6657 \pm 0.00 \mathrm{a}$ & $0.659 \pm 0.005$ & $0.656 \pm 0.004$ & $0.650 \pm 0.004$ & $0.646 \pm 0.005$ & $0.6528 \pm 0.005 c$ \\
\hline$T_{3}$ & $0.676 \pm 0.004$ & $0.661 \pm 0.004$ & $0.655 \pm 0.004$ & $0.643 \pm 0.003$ & $0.6589 \pm 0.013 b$ & $0.656 \pm 0.03$ & $0.655 \pm 0.003$ & $0.649 \pm 0.004$ & $0.644 \pm 0.006$ & $0.6510 \pm 0.005 \mathrm{c}$ \\
\hline Mean & $0.6777 \pm 0.004 \mathrm{~A}$ & $0.6672 \pm 0.00 B$ & $0.6627 \pm 0.00 \mathrm{C}$ & $0.6508 \pm 0.0 \mathrm{D}$ & & $0.6626 \pm 0.0 \mathrm{~A}$ & $0.6602 \pm 0.00 \mathrm{~A}$ & $0.6541 \pm 0.5 B$ & $0.6482 \pm 0.04 C$ & \\
\hline \multicolumn{11}{|l|}{ Color } \\
\hline $\mathrm{T}_{0}$ & $115 \pm 4$ & $111 \pm 4$ & $110 \pm 2$ & $102 \pm 4$ & $109.75 \pm 5 a$ & $125 \pm 3$ & $120 \pm 3$ & $111 \pm 3$ & $106 \pm 3$ & $115.83 \pm 9 a$ \\
\hline $\mathrm{T}_{1}$ & $110 \pm 3$ & $103 \pm 3$ & $102 \pm 2$ & $99 \pm 1$ & $103.50 \pm 5 b$ & $122 \pm 2$ & $119 \pm 4$ & $110 \pm 3$ & $100 \pm 2$ & $112.67 \pm 10 b$ \\
\hline $\mathrm{T}_{2}$ & $111 \pm 5$ & $106 \pm 4$ & $98 \pm 3$ & $95 \pm 3$ & $102.58 \pm 7 b$ & $121 \pm 3$ & $117 \pm 3$ & $106 \pm 3$ & $100 \pm 3$ & $110.92 \pm 10 \mathrm{bc}$ \\
\hline$T_{3}$ & $107 \pm 3$ & $105 \pm 2$ & $92 \pm 3$ & $90 \pm 2$ & $98.67 \pm 9 \mathrm{c}$ & $119 \pm 1$ & $118 \pm 3$ & $104 \pm 2$ & $99 \pm 1$ & $109.92 \pm 10 c$ \\
\hline Mean & $110.92 \pm 3 \mathrm{~A}$ & $106.33 \pm 3 B$ & $100.67 \pm 8 C$ & $96.58 \pm 5 \mathrm{D}$ & & $121.83 \pm 3 \mathrm{~A}$ & $118.42 \pm 1 \mathrm{~B}$ & $107.50 \pm 3 C$ & $101.58 \pm 3 D$ & \\
\hline \multicolumn{11}{|l|}{ Texture } \\
\hline$T_{0}$ & $985.47 \pm 4.90$ & $986.83 \pm 4.31$ & $988.53 \pm 5.68$ & $991.10 \pm 4.09$ & $987.98 \pm 2.42 \mathrm{~A}$ & $969.3 \pm 3.4$ & $973.9 \pm 3.1$ & $976.7 \pm 4.0$ & $978.3 \pm 3.2$ & $974.57 \pm 3.9 \mathrm{AB}$ \\
\hline $\mathrm{T}_{1}$ & $984.33 \pm 5.06$ & $984.83 \pm 5.41$ & $985.60 \pm 4.90$ & $991.37 \pm 3.00$ & $986.53 \pm 3.26 \mathrm{~A}$ & $974.8 \pm 3.9$ & $976.6 \pm 4.6$ & $977.5 \pm 4.2$ & $979.1 \pm 3.8$ & $977.00 \pm 1.8 \mathrm{~A}$ \\
\hline $\mathrm{T}_{2}$ & $979.37 \pm 4.16$ & $981.97 \pm 3.0$ & $986.40 \pm 5.47$ & $992.90 \pm 4.37$ & $985.16 \pm 5.9 \mathrm{~A}$ & $971.6 \pm 3.6$ & $976.0 \pm 4.8$ & $978.4 \pm 4.3$ & $980.0 \pm 4.4$ & $976.49 \pm 3.6 \mathrm{AB}$ \\
\hline$T_{3}$ & $983.73 \pm 4.92$ & $984.53 \pm 4.4$ & $986.33 \pm 5.65$ & $994.33 \pm 3.74$ & $987.23 \pm 4.85 \mathrm{~A}$ & $968.9 \pm 3.6$ & $970.0 \pm 3.0$ & $974.7 \pm 3.3$ & $979.6 \pm 5.0$ & $973.30 \pm 4.9 B$ \\
\hline
\end{tabular}

Values are mean of three replicates \pm SD. Means followed by different letters are significant different $(p<0.05)$. 
Water activity $\left(\mathrm{a}_{\mathrm{w}}\right)$ is the most important property of water in food system. Scott (1957) reported that there is an optimum water activity level below that the micro organism cannot grow well. The results showed that the different treatments of extruded flaxseed have significant effect on water activity of leg meat nuggets. Water activity of leg meat nuggets ranged from 0.683-0.676. During storage the water activity of leg mat nuggets decreased as the time period increased. At 0 day all the treatments have higher water activity as compared to the 10, 20 and 30 days. The lowest water activity was observed at 30 in all treatments. Water activity of breast meat nuggets ranged from 0.671-0.656. During storage the breast meat nuggets water activity behavior was same as that of leg mat nuggets. The water activity decreased with the passage of time during storage and minimum water activity was observed at day 30 . The results of my study are in contrast with the findings of [41] who observed no change in water activity in omega enriched sausage during storage. This variation in results may be due to the different level of enrichment or different storage conditions.

Food appearance is one of the major factors that determine the consumer acceptance and ultimately the sale of product. Food quality and shelf life is limited by the oxidation of polyunsaturated fatty acids and bacterial contamination. The results revealed a highly significant effect of different treatment of extruded flaxseed and storage days on color of the broiler meat nuggets. However the interactive effect of treatments and storage days was significant. The color of leg meat nuggets ranged from 115-107. During storage the values for the color decreased with the passage of time. The decrease in value indicated that the nuggets become darker during storage. In $\mathrm{T}_{3}$ minimum value 90 was observed at day 30. The color values decreased in all the treatments of extruded flaxseed during storage. The color values for breast meat nuggets fanged from 125-119. During storage the breast meat nuggets showed the same behavior as the leg meat nuggets. The color values tend to decrease with the storage days increase. The values for color decreased from 0 day to 30 days to the lowest level in all the treatments of extruded flaxseed. The results of my study are in close collaboration with the finding of [42], who studied the color characteristics of omega enriched sausages and found that the color become dark with the passage of time.

Texture is an important tool to check the acceptability of meat products during its storage period. The texture values of leg meat nuggets ranged from 969.3-974.8. During storage the texture values increased with the increase in storage days. The texture value in all the treatments ranged from 969.3 to 974.8 at 0 day which tend to increase 978.3-980.0 at day 30. During storage the breast meat nuggets followed the same pattern as leg meat nuggets. The texture values tend to increase with the storage days. At 0 days the texture values for all the treatments ranged 979.37-985.47 which increased to 991.10-994.33 at day 30. The increase in hardness may be associated with the decrease in water activity of the nuggets with the advancement of storage period. The results of present study are in close collaboration with [43] who stated that the texture value varied significantly with the advancement of storage period.

\section{Sensory evaluation of nuggets}

The development of new food products by modification of ingredients or processing conditions, cost reduction and quality control, often employs sensory evaluation techniques to determine the acceptability of food [44].

Aroma of a product is an important factor involving in the consumer acceptance. It also has contribution in flavor of the product. There was a significant effect of storage and treatments on aroma of nuggets and nonsignificant results obtained by the interaction of treatments and storage. The results of sensory evaluation presented in table (Table 7) showed that there was a significant decrease in likeness of aroma from 0day to 30 days of storage at freezing temperature. The results pertaining to aroma revealed that $\mathrm{T}_{0}$ was preferred by the judges because it gave excellent aroma to nuggets and obtained 7 , followed by $\mathrm{T}_{1}$ (6.5 points). $\mathrm{T}_{3}$ containing maximum level of extruded flaxseed obtained minimum points for aroma by the panel of judges. The aroma tends to less acceptable as the flaxseed level and storage days increased. Minimum score for aroma was observed in $\mathrm{T}_{3}$ at day 30 which was 5 . The results of my study for aroma are in contrast with [14] who stated that there was no effect of flaxseed levels on the aroma of omega enriched meat products.

Flavor is an important parameter in sensory evaluation of a food product; it is the combined perception of smell, taste and mouth feel, making attraction for the consumers. It was obvious from the results that the treatments and storage days had significant effect on the flavor of nuggets; however the interactive effect of treatments and storage days was not significant. The nuggets from the control treatments obtained highest score for the flavor in all the treatments. The flavor values tend to decrease as the level of extruded flaxseed increased. During storage flavor value decreased with the storage days. The minimum value for flavor was observed in $T_{3}(5.25)$ at day 30. The decrease in flavor value is due to the peroxidation of PUFA which results in off flavors and bad odors [45].

Taste is a very important attribute for the acceptance of a food product. The results showed that there was significant effect of treatments and storage days on taste of nuggets. The mean values revealed that $T_{0}$ and $T_{1}$ were 
Table 7 Aroma, flavor, taste and overall acceptability of nuggets of leg and breast meat of broilers fed on Extruded Flaxseed

\begin{tabular}{|c|c|c|c|c|c|c|c|c|c|c|}
\hline \multirow{2}{*}{$\begin{array}{c}\text { Treatment } \\
\text { Aroma }\end{array}$} & \multicolumn{5}{|c|}{ Breast meat nuggets } & \multicolumn{5}{|c|}{ Leg meat nuggets } \\
\hline & 0 day & 10 day & 20 day & 30 day & Mean & 0 day & 10 day & 20 day & 30 day & Mean \\
\hline $\mathrm{T}_{0}$ & $7 \pm 0.50$ & $7 \pm 0.40$ & $7 \pm 0.0$ & $6 \pm 0.50$ & $6.75 \pm 0.50 \mathrm{~A}$ & $6.5 \pm 0.40$ & $6.3 \pm 0.40$ & $6.2 \pm 0.70$ & $6 \pm 0.50$ & $6.25 \pm 0.50 \mathrm{~A}$ \\
\hline $\mathrm{T}_{1}$ & $7 \pm 0.50$ & $7 \pm 0.80$ & $6.5 \pm 0.5$ & $5.75 \pm 0.70$ & $6.5 \pm 0.60 \mathrm{AB}$ & $6.4 \pm 0.60$ & $6.1 \pm 0.80$ & $5.8 \pm 0.60$ & $5.5 \pm 0.80$ & $5.95 \pm 0.70 \mathrm{~B}$ \\
\hline $\mathrm{T}_{2}$ & $6.5 \pm 0.50$ & $6.5 \pm 0.25$ & $6 \pm 0.4$ & $5.5 \pm 0.25$ & $6 \pm 0.40 \mathrm{BC}$ & $6.2 \pm 0.50$ & $6.1 \pm 0.60$ & $5.7 \pm 0.50$ & $5.4 \pm 0.30$ & $5.85 \pm 0.45 B$ \\
\hline$T_{3}$ & $6 \pm 0.40$ & $6 \pm 0.25$ & $6 \pm 0.0$ & $5 \pm 0.50$ & $5.75 \pm 0.50 \mathrm{C}$ & $6.2 \pm 0.80$ & $5.8 \pm 0.50$ & $5.6 \pm 0.30$ & $5.2 \pm 0.50$ & $5.7 \pm 0.55 \mathrm{C}$ \\
\hline Mean & $6.508 \pm 0.5 \mathrm{~A}$ & $6.625 \pm 0.50 \mathrm{~A}$ & $6.4 \pm 0.50 \mathrm{~A}$ & $5.50 \pm 0.40 \mathrm{~B}$ & & $6.25 \pm 0.55 \mathrm{~A}$ & $6.05 \pm 0.0 .60 \mathrm{~B}$ & $5.85 \pm 0.50 \mathrm{C}$ & $5.55 \pm 0.45 \mathrm{D}$ & \\
\hline \multicolumn{11}{|l|}{ Flavor } \\
\hline $\mathrm{T}_{0}$ & $7.5 \pm 0.40$ & $7 \pm 0.75$ & $7 \pm 0.00$ & $6 \pm 0.50$ & $6.87 \pm 0.60 \mathrm{~A}$ & $7 \pm 0.60$ & $6 \pm 0.40$ & $6 \pm 0.50$ & $5 \pm 0.30$ & $6 \pm 0.35 B$ \\
\hline $\mathrm{T}_{1}$ & $7 \pm 0.50$ & $6.5 \pm 0.30$ & $6.5 \pm 0.50$ & $5.75 \pm 0.70$ & $6.45 \pm 0.51 \mathrm{~B}$ & $6.5 \pm 0.50$ & $6.5 \pm 0.50$ & $6 \pm 0.60$ & $6 \pm 0.20$ & $6.2 \pm 0.45 \mathrm{~A}$ \\
\hline $\mathrm{T}_{2}$ & $7 \pm 0.50$ & $6 \pm 0.50$ & $6 \pm 0.40$ & $5.5 \pm 0.25$ & $6.20 \pm 0.62 \mathrm{BC}$ & $6.5 \pm 0.73$ & $6 \pm 0.45$ & $5 \pm 0.40$ & $5 \pm 0.65$ & $5.62 \pm 50 \mathrm{C}$ \\
\hline$T_{3}$ & $6.5 \pm 0.25$ & $6 \pm 0.25$ & $6 \pm 0.00$ & $5 \pm 0.50$ & $5.87 \pm 0.62 \mathrm{C}$ & $6 \pm 0.66$ & $5.5 \pm 0.40$ & $5.5 \pm 0.70$ & $5 \pm 0.40$ & $5.5 \pm 0.50 \mathrm{C}$ \\
\hline Mean & $7 \pm 0.40 \mathrm{~A}$ & $6.43 \pm 0.50 \mathrm{~B}$ & $6.40 \pm 0.50 \mathrm{~B}$ & $5.56 \pm 0.43 C$ & & $6.5 \pm 0.60 \mathrm{~A}$ & $6 \pm 0.45 B$ & $5.75 \pm 0.60 \mathrm{C}$ & $5.25 \pm 0.35 \mathrm{D}$ & \\
\hline \multicolumn{11}{|l|}{ Taste } \\
\hline T0 & $7 \pm 0.50$ & $7 \pm 0.40$ & $7 \pm 0.00$ & $6 \pm 0.50$ & $6.75 \pm 0.50 \mathrm{~A}$ & $7 \pm 0.25$ & $7 \pm 0.40$ & $6 \pm 0.50$ & $5 \pm 0.45$ & $6.24 \pm 0.40 \mathrm{~A}$ \\
\hline $\mathrm{T} 1$ & $7 \pm 0.50$ & $7 \pm 090$ & $6.5 \pm 0.50$ & $5.75 \pm 0.66$ & $6.58 \pm 0.60 \mathrm{~A}$ & $7 \pm 0.45$ & $6 \pm 0.50$ & $6 \pm 0.60$ & $6 \pm 0.50$ & $6.25 \pm 0.50 \mathrm{~A}$ \\
\hline $\mathrm{T} 2$ & $6.5 \pm 0.50$ & $6.5 \pm 0.25$ & $6 \pm 0.40$ & $5.5 \pm 0.25$ & $6.14 \pm 0.50 \mathrm{~B}$ & $6 \pm 0.50$ & $6 \pm 0.35$ & $5 \pm 0.50$ & $5 \pm 0.25$ & $5.5 \pm 0.40 \mathrm{C}$ \\
\hline T3 & $6 \pm 0.40$ & $6 \pm 0.25$ & $6 \pm 0.00$ & $5 \pm 0.50$ & $5.7708 \pm 0.50 \mathrm{~B}$ & $6 \pm 0.60$ & $6 \pm 0.40$ & $5.5 \pm 0.40$ & $5 \pm 0.35$ & $5.75 \pm 0.45 B$ \\
\hline Mean & $6.64 \pm .0 .50 \mathrm{~A}$ & $6.64 \pm 0.50 \mathrm{~A}$ & $6.39 \pm 0.50 \mathrm{~A}$ & $5.56 \pm 0.43 B$ & & $6.5 \pm 0.40 \mathrm{~A}$ & $5.75 \pm 0.40 \mathrm{~B}$ & $5.65 \pm 0.40 \mathrm{C}$ & $5.25 \pm 00.35 \mathrm{D}$ & \\
\hline \multicolumn{11}{|c|}{ Overall acceptability } \\
\hline $\mathrm{T}_{0}$ & $7.25 \pm 0.43$ & $7 \pm 0.43$ & $7 \pm 0.50$ & $6 \pm 0.43$ & $6.81 \pm 0.55 \mathrm{~A}$ & $7 \pm 0.45$ & $7 \pm 0.50$ & $6 \pm 0.40$ & $5 \pm 0.45$ & $6.25 \pm 0.45 B$ \\
\hline $\mathrm{T}_{1}$ & $7 \pm 0.50$ & $6.75 \pm 0.43$ & $6.5 \pm 0.50$ & $5.75 \pm 0.50$ & $6.50 \pm 0.54 \mathrm{AB}$ & $8 \pm 0.55$ & $7 \pm 0.30$ & $6 \pm 0.30$ & $6 \pm 0.40$ & $6.75 \pm 0.40 \mathrm{~A}$ \\
\hline$T_{2}$ & $6.5 \pm 0.50$ & $6.5 \pm 0.25$ & $6.25 \pm 0.50$ & $5.5 \pm 0.50$ & $6.18 \pm 0.47 \mathrm{BC}$ & $7 \pm 0.60$ & $6 \pm 0.20$ & $5 \pm 0.50$ & $5 \pm 0.60$ & $5.75 \pm 0.45 C$ \\
\hline$T_{3}$ & $6.25 \pm 0.43$ & $6 \pm 0.25$ & $6 \pm 0.50$ & $5 \pm 0.50$ & $5.81 \pm 0.55 \mathrm{C}$ & $6 \pm 0.40$ & $6 \pm 0.40$ & $5 \pm 0.60$ & $5 \pm 0.50$ & $5.50 \pm 0.40 \mathrm{D}$ \\
\hline Mean & $6.75 \pm 0.45 \mathrm{~A}$ & $6.56 \pm 0.43 \mathrm{~A}$ & $6.43 \pm 0.43 \mathrm{~A}$ & $5.56 \pm 0.43 B$ & & $7 \pm 0.50 \mathrm{~A}$ & $6.5 \pm 0.30 \mathrm{~B}$ & $5.5 \pm 0.45 C$ & $5.25 \pm 0.50 \mathrm{D}$ & \\
\hline
\end{tabular}

Values are mean of three replicates \pm SD. Means followed by different letters are significant different $(p<0.05)$.

much liked by the judges and got highest score, [7] and $\mathrm{T}_{3}$ got minimum score [4] at 0 day. During storage the score for taste of nuggets decreased and minimum score was obtained by $\mathrm{T}_{3}[6]$ at day 30 . The decreasing trend in taste of nuggets may be associated with the peroxidation of poly unsaturated fatty acids.

Overall acceptability is another important parameter in sensory evaluation of a product. It determines on the basis of quality scores obtained from aroma, taste, and flavor. The results showed that overall acceptability of nuggets was significantly affected by different treatments while the storage affect was non-significant. $\mathrm{T}_{0}$ was highly acceptable by the panelists as got highest score for overall acceptability [7] while $T_{3}$ got minimum score [6] for the overall acceptability at day 30 . The results of my study are in agreement with [46] who stated that the overall acceptability decrease with increase in omega enrichment in meat products.

\section{Conclusion}

The present study was designed to investigate the relationship of various quality attributes and storage stability of broiler meat and meat products with different concentrations of extruded flaxseed fed to the broiler birds. The supplementation of extruded flaxseed in the diet of broiler birds resulted decrease in the body weight, feed intake and higher FCR values. $\mathrm{T}_{3}$ (15\% extruded flaxseed) achieved lowest weight and feed intake. The antioxidant enzyme assay resulted in significant difference among treatments. The chemical analysis of extruded flaxseed fed meat revealed that the fat contents of leg meat greatly increased as compared to breast meat. Maximum fat contents were observed in $T_{3}$ (15\% extruded flaxseed). Thiobarbituric acid reactive substances (TBARS) were evaluated in the form of $n$-moles of malondialdehyde by thiobarbituric acid test which showed the lipid oxidation stability of meat. $T_{3}$ showed the highest amount of nmole of malondialdehyde which revealed that this group has lowest lipid stability than other groups in this study. Free radical scavenging activity improved in meat by supplementation of higher concentration of extruded flaxseed in diet. The results showed the maximum free radical scavenging activity was found in T3. Fatty acid 
profile was determined by Gas Chromatography. The results showed higher omega-3 contents in higher level of extruded flaxseed fed meat. Omega-3 fatty acids were deposited according to dose supplemented in the meat. The maximum omega- 3 contents were observed in T3 having highest level of extruded flaxseed (15\%) than all the other treatments of study. The results from storage study revealed the significant effect of storage on the physicochemical and sensory properties of omega enriched meat nuggets. In the present study it is concluded that as the concentration omega- 3 fatty acids increased in broiler meat with the higher level of extruded flaxseed supplementation in diet. Extruded flaxseed supplemented feed increased the total fat contents but decreased the oxidative stability of omega- 3 enriched meat. High levels of extruded flaxseed negatively affected the physicochemical and sensory properties of omega-3 enriched nuggets during storage.

The present study concluded that as the concentration of omega-3 fatty acids increased in broiler meat with the higher level of extruded flaxseed supplementation in diet. Extruded flaxseed supplemented feed increased the total fat contents but decreased the oxidative stability of omega-3 enriched meat. High levels of extruded flaxseed negatively affected the physicochemical and sensory properties of omega-3 enriched nuggets during storage.

\section{Abbreviation \\ MDA: Malondialdehydes ALA; TBARS: Thiobarbituric Acid Reactive Oxygen \\ Species; HPLC: High-Performance Liquid Chromatography; GC: Gas \\ Chromatography; PUFA: Poly Unsaturated Fatty Acids.}

\section{Competing interests}

The authors report no conflicts of interest. The authors alone are responsible for the content and writing of the paper.

\section{Authors' contribution}

MFHB and MSA carried out the experimental trial of the broilers and also collected data of this research. They also arranged all the data and drafted the manuscript. FMAA provides technical assistance during research of the broiler and also guided in the analysis and statistical design of research trial. MIKC and MSAE also helped to carry out the analytical research work and analysis of the meat and meat products. "It's also confirmed that all the authors read and approved the final manuscript".

\section{Acknowledgement}

The authors wish to express sincere thanks to National Institute of Food Science and Technology, University of Agriculture, Faisalabad, Pakistan for providing financial assistance to carry out this research work.

Received: 15 December 2012 Accepted: 31 January 2013 Published: 8 February 2013

\section{References}

1. Bhatty RS: Nutritional composition of whole flaxseed and flaxseed meal. In Flaxseed in human nutrition. Edited by Cunnane SC, Thompson LH. Champaign, IL: AOCS Press; 1995.

2. Carter JF: Potential of flaxseed and flaxseed oil in baked goods and other products in human nutrition. Cereal Foods World 1993, 38(10):753-759.

3. Diederichsen A, Richards KW: Cultivated flax and the genus linum L.-taxonomy and germplasm conservation. In Flax, the genus linum. Edited by Muir A, Westscott N. London, UK: Taylor \& Francis; 2003:22-54.
4. Palmquist DL: Omega-3 fatty acids in metabolism, health, and nutrition and for modified animal product foods. Prof I Animal Sci 2009, 25:207-249.

5. Oomah BD, Mazza G: Flaxseed proteins - a review. Food Chem 1993, 48:109-114.

6. Dale N, Batal A: Feedstuffs reference issue and buyers guide. Feedstuffs 2008, 79:17-20.

7. Schmitz G, Ecker J: The opposing effects of $n-3$ and $n-6$ fatty acids $J$ of Lipid Res 2008, 47:147-155.

8. Mukhopadhyay N, Sarkar S, Bandyopadhyay S: Effect of extrusion cooking on anti-nutritional factor tannin in linseed (linum usitatissimum) meal. Int J of Food Sci and Nutri 2007, 58(8):588-594.

9. Yashodhara BM, Umakanth S, Pappachan JM, Bhat SK, Kamath R, Choo BH: Omega-3 fatty acids, a comprehensive review of their role in health and disease. Postgraduate Med J 2009, 85:84-90.

10. Wu J, Johnson LA, Jung S: Demulsification of oil-rich emulsion from enzyme-assisted aqueous extraction of extruded soybean flakes. Bioresource Technol 2009, 100:527-533.

11. Xu CZ, Wang QJ, Zheng MS, Zhu JW, Li JD, Huang MQ, Jia QM, Du ZZ: Microstructure and properties of ultra-fine grain $\mathrm{Cu}-\mathrm{Cr}$ alloy prepared by equal-channel angular pressing mater. Engineering and Sci 2007, 459:303-308.

12. Martínez-Flores HE, Barrera ES, Garnica-Romo MG, Penagos CJC, Saavedra JP, Macazaga-Alvarez R: Functional characteristics of protein flaxseed concentrate obtained applying a response surface methodology. J of Food Sc 2006, 71:495-498.

13. Wu M, Li D, Wang L, O'zkan N, Mao ZH: Rheological properties of extruded dispersions of flaxseed-maize blend. J Food Eng 2010, 98:480-491.

14. Betti M, Perez TI, Zuidhof MJ, Renema RA: Omega-3 enriched broiler meat, 3 fatty acid distribution between triacylglycerol and phospholipid classes. Poult Sci 2009, 88:1740-1754.

15. Wu M, Li D, Wang L, Zhou Y, Brooks MS, Chen XD: Extrusion detoxification technique on flaxseed by uniform design optimization. Sep Purif Technol 2008, 61(1):51-59.

16. Minami $M$, Yoshikawa $\mathrm{H}$ : A simplified assay method of superoxide dismutase activity for clinical use. Clinica Chimica Acta 1979, 92:337-342.

17. Aebi H: Catalase estimation. In Methods of enzymatic analysis. Edited by Bergmeyer HU. Weinheim, New York: Verlag chemic; 1974:673-684.

18. Helen A, Vijayammal PL: Vitamin C supplementation on hepatic oxidative stress induced cigarette smoke. J App/ Toxicol 1997, 17:289-295.

19. Beutler E, Duron O, Kelly BM: Improved method for the determination of blood glutathione. J Lab Clin Med 1983, 61:882-888.

20. Brand-Williams W, Cuvelier ME, Berset C: Use of a free radical method to evaluate antioxidant. Lebensm.- Wissenschaft u.-Techno 1995, 28:25-30.

21. Ahn DU, Sell JL, Chen CJX, Wu C, Lee Jl: Effects of dietary vitamin E supplementation on lipid oxidation and volatiles content of irradiated, cooked turkey meat patties with different packaging. Poult Sci 1998, 6:912-920.

22. Sukhiia P, Palmquist DL: Rapid method for determination of total fatty acid content and composition of feedstuffs and feaces. J of Agri and Food Chem 1988, 86:1202-1206.

23. Perlo F, Bonato P, Teira G, Marcuzzi A: Influencia del nu' Mero de lavados en el procesamiento de carne de ave meca' nicamente recuperada. Ciencia y Tecnología Alimentaria 2003, 4(1):55-59.

24. Sallama Kl, Ishioroshib M, Samejima K: Antioxidant and antimicrobial effects of garlic in chicken sausage. Lebensm.- Wissenschaft u.-Technol. 2004, 37:849-855.

25. El-Gasim EA, Al-Wesali MS: Water activity and hunter color values of beef patties extended with samh (mesembryanthemum forsskalei hochst) flour. Food Chem 2000, 69:181-185.

26. Cosenza GH, Williams SKD, Johnson D, Sims C, McGowan CH: Development and evaluation of a cabrito smoked sausage product. Meat Sci 2003, 64:119-124.

27. Carlos ML, Mendes RC, Maria LN: Instrumental texture and sensory characteristics of cod frankfurter sausages. Int J I of Food Propert 2009, 12:625-643.

28. Meilgaard MM, Civille GV, Carr T: Overall difference tests, Does a sensory difference exist between samples? Sensory evaluation techniques. 4th edition. New York: USA; 2007:63-104.

29. Steel RGD, Torrie JH, Dickey D: Principles and procedures of statistics, a biometrical approach. 3rd edition. New York: McGraw Hill Book Co Inc; 1997.

30. Shen Y, Feng D, Oresanya T, Chavez E: Fatty acid and nitrogen utilization of processed flaxseed by adult chickens. J Sci Food Agri 2005, 85:1137-1142. 
31. Rodriguez ML, Alzueta C, Rebole A, Ortiz LT, Centeno C, Trevino J: Effect of inclusion level of linseed on the nutrient utilisation of diets for growing broiler chickens. British Poult Sci 2001, 42:368-375.

32. Zuidhof MJ, Betti M, Korver DR, Hernandez FIL, Schneider BL, Carney VL, Renema RA: Omega-3-enriched broiler meat, 1. Optimization of a production system. Poult Sci 2009, 88:1108-1120,

33. Nguyen CV, Smulikowska S, Mieczkowska A: Effect of linseed and rapeseed or linseed and rapeseed oil on performance, slaughter yield and fatty acid deposition in edible parts of the carcass in broiler chickens. J Anim Feed Sci 2003, 12:271-288.

34. Maraschiello C, Sa' rraga C, Garcia Regueiro JA: Glutathione peroxidase activity, TBARS, and a-tocopherol in meat from chickens Fed different diets. J Agri Food Chem 1999, 1999(47):867-872.

35. Rodriguez-Martinez MA, Ruiz-Torres A: Homeostasis between lipid peroxidation and antioxidant enzyme activities in healthy human aging. Mech Ageing Dev 2001, 66:213-222.

36. Luna A, Labaque MC, Zygadlo JA, Marin RH: Effects of thymol and carvacrol feed supplementation on lipid oxidation in broiler meat. Poult Sci 2010, 89:366-370

37. Zanini SF, Colnago GL, Bastos MR, Pessotti BMS, Casagrande FP, Lima VR: Oxidative stability and total lipids on thigh and breast meat of broilers fed diets with two fat sources and supplemented with conjugated linoleic acid. LWT- Food Sci Technol 2006, 39:717-723.

38. Bradley PA, Edel AL, McCullough R, Rodriguez-Leyva D, Rampersad P, Gilchrist JSC, Lukas A, Pierce GN: Distribution of omega-3 fatty acids in tissues of rabbits fed a flaxseed-supplemented diet. Metab Clin Exp 2010, 2010(59):620-627.

39. Juarez M, Dugan MER, Aldai N, Aalhus JL, Patience JF, Zijlstra RT, Beaulieu AD: Increasing omega-3 levels through dietary co-extruded flaxseed supplementation negatively affects pork palatability. Food Chem 2010, 126:1716-1723.

40. Jeun-Hornga L, Yuan-Huib L, Chun-Chinc K: Effect of dietary fish oil on fatty acid composition, lipid oxidation and sensory property of chicken frankfurters during storage. Meat Sci 2002, 60:161-167.

41. Ca' ceres E, Garcia ML, Selgas MD: Effect of pre-emulsified fish oil as source of PUFA $n-3$ on microstructure and sensory properties of mortadella, a Spanish bologna-type sausage. Meat Sci 2008, 80:183-193.

42. Hoz L, D'Arrigo M, Cambero I, Ordonez JA: Development of an n-3 fatty acid and a-tocopherol enriched dry fermented sausage. Meat Sci 2004 67(3):485-495

43. Sohaib M, Anjum FM, Khan MI, Arshad MS, Shahid M: Enhancement of lipid stability of broiler breast meat and meat products fed on alpha lipoic acid and alpha tocopherol acetate supplemented feed. J Lipids health Dis 2012, 11:57.

44. Barbut S: Poultry products processing, an industry guide. Boca Raton, Florida: CRC Press; 2002

45. Woods VB, Fearon EA: Dietary sources of unsaturated fatty acids for animals and their transfer into meat, milk and eggs, a review. Livest Sci 2009, 126:1-20.

46. Valencia I, Ansorena D, Astiasaran I: Nutritional and sensory properties of dry fermented sausages enriched with n-3 PUFAs. Meat Sci 2006, 72(4):727-733

\section{doi:10.1186/1476-511X-12-13}

Cite this article as: Anjum et al: Impact of extruded flaxseed meal supplemented diet on growth performance, oxidative stability and quality of broiler meat and meat products. Lipids in Health and Disease 2013 12:13

\section{Submit your next manuscript to BioMed Central and take full advantage of:}

- Convenient online submission

- Thorough peer review

- No space constraints or color figure charges

- Immediate publication on acceptance

- Inclusion in PubMed, CAS, Scopus and Google Scholar

- Research which is freely available for redistribution 